\title{
Effect of Storage Method on Fermentation Characteristics, Aerobic Stability, and Forage Intake of Tropical Grasses Ensiled in Round Bales ${ }^{1}$
}

\author{
G. González, and A. A. Rodríguez \\ Deparment of Animal Science, \\ University of Puerto Rico, Mayagüez Campus, Mayagüez 00681
}

\section{ABSTRACT}

The effect of storage method and length of the fermentation period were evaluated to determine fermentation characteristics, aerobic stability, and forage intake of native tropical grasses ensiled in round bales. Bales were stored under shade or under direct sunlight and sampled after seven periods of ensiling $(0,1,4,11,25$, 53 , and $111 \mathrm{~d}$ ). For the aerobic stability and nutritive value studies, three bales were opened from each storage method after 53 and $111 \mathrm{~d}$, exposed to air, and fed to heifers for voluntary consumption. The storage method did not affect fermentation characteristics, however, during aerobic exposure, silage storage under shade resulted in less deterioration as evidenced by lower $\mathrm{pH}$, temperature, and microbial populations. Also, the shorter length of fermentation ( $53 \mathrm{~d}$ ) resulted in lower $\mathrm{pH}$ and temperature and enhanced aerobic stability. The combination of silage storage under shade and short length of fermentation resulted in the most stable silages and did not improve the nutritive value of native tropical grasses ensiled in large round bales as evidenced by similar forage intake.

(Key words: storage method, length of fermentation, tropical silage, round bales)

Abbreviation key: LAB = lactic acid-producing bacteria, $\mathbf{L F}=$ length of fermentation, $\mathbf{N T G}=$ native tropical grasses, $\mathbf{S M}=$ storage method, $\mathbf{W S C}=$ water soluble carbohydrates.

\section{INTRODUCTION}

Forages represent the most abundant and economical source for ruminant nutrition in the tropics. However, it is crucial to have reserves of forage for use during

Received September 5, 2002.

Accepted October 23, 2002.

Corresponding author: A. A. Rodríguez; e-mail: carias_abner@ hotmail.com.

${ }^{1}$ Funding for this research was provided by USDA/T-STAR Grant \#97-34135-4717. times of drought over the yearly climatic cycle. In Puerto Rico, the production of silages has increased in recent years, to the point of replacing hay production on most farms. Compared with hay, silage is easier to handle and substantially reduces rain damage, and field losses (Wilkinson, 1983).

Tower silos, bunkers, and bags are the structures commonly used for silage storage in temperate climates. In Puerto Rico the production of round bale silage has become an integral part of feeding systems for dairy and beef cattle. However, round bale storage generally results in poor fermentation, and silages are susceptible to aerobic deterioration with low nutritive value. These silages are also associated with clostridial fermentations, resulting in poor acceptability and low voluntary intake due to high contents of ammonia and amines (Harrison et al., 1994). Also, studies in the tropics with round bales (Rodríguez et al., 2000) showed that the plastic wrap of the bales deteriorated after long periods of storage, which promotes secondary silage fermentation in the aerobic phase.

The storage of round bales under direct sunlight could be a contributing cause of deteriorated silage during fermentative process, aerobic exposure, and animal utilization. Vough and Glick (1993) believe that this deterioration is caused by the movement of humidity through the bale; the water evaporates during the day, and condenses on the top and external surfaces at night. In temperate climates, storing round bale silage under shade improves fermentation characteristics (Vough and Glick, 1993). Also, Weinberg et al. (2001) and Rodríguez et al. (1998) demonstrated that higher temperatures promote microbial activities and negatively affect the fermentation process and aerobic stability. Moreover, it was shown that the population of yeasts and molds are positively associated with the concentrations of water-soluble carbohydrates (WSC), lactic acid, and lactic acid-producing bacteria (LAB) in silage before aerobic exposure (Weinberg et al., 1993).

This study was designed to evaluate the effect of storage method (SM; under shade or direct sunlight) and length of fermentation on the fermentation characteris- 
tics, aerobic stability, and forage intake of native tropical grasses ensiled in round bales.

\section{MATERIALS AND METHODS}

\section{Vegetative Material}

A mature stand of native tropical grasses (NTG), similar to the type of forage ensiled by many farmers, (70\% Panicum maximun, 30\% Sorghum halapense) was harvested at the Agricultural Experimental Station of the University of Puerto Rico located in the southwest region of the island. Before ensiling, samples of fresh material were analyzed to determine $\mathrm{pH}, \mathrm{DM}$ content $\left(65^{\circ} \mathrm{C}\right.$ for $\left.48 \mathrm{~h}\right)$, ash $\left(550^{\circ} \mathrm{C}\right.$ for $\left.12 \mathrm{~h}\right), \mathrm{N}$ (AOAC, 1990$)$, WSC (Dubois et al., 1956), structural carbohydrates (Van Soest et al., 1991), and epiphitic microflora. The forage were chopped, packed, and ensiled with commercial machinery (Claas Rollant 46 roto cut) in 36 round bales of approximately $350 \mathrm{~kg}$ capacity. Bales were randomly assigned for storage under shade or under direct sunlight. Shade was provided using a storage area under a metal roof with an open side and a concrete floor.

\section{Fermentation Process}

After seven periods $(0,1,4,11,25,53$, and $111 \mathrm{~d})$ of fermentation, eight core samples from the center of each bale corresponding to each storage method were collected in triplicate, with a forage sampler (Penn State Sampler; $3.5 \mathrm{~cm}$ diameter and $40 \mathrm{~cm}$ long; Nasco, Ft. Atkinson, WI). Subsamples were homogenized, and the final sample was used to determine acidity, changes in chemical composition, microbial succession, and fermentation end products. To determine acidity, $50 \mathrm{~g}$ of sample and $450 \mathrm{ml}$ of distilled water were mixed, homogenized in a Stomacher 3500 laboratory blender (Seward Medical Limited, England) for $6 \mathrm{~min}$, and filtered through cheesecloth. The extract of the homogenized sample was used to measure $\mathrm{pH}$ with a combination electrode. This extract was used in serial dilutions $\left(10^{-2}\right.$ to $\left.10^{-8}\right)$ with sterilized peptone to enumerate three types of organism. Enumeration of LAB (Rogosa SL Agar, Difco Laboratories, Detroit, MI), enterobactericeae (Violet Red Agar; supplemented with sucrose 0.5\%, Difco Laboratories, Detroit, MI), and yeasts and molds (Rose Bengal Agar Base supplemented with Chloramphenicol, Difco Laboratories, Detroit, MI) were conducted using the pour plate technique. All petri dishes were incubated at $38^{\circ} \mathrm{C}$ and manually counted after a specific incubation time for each type of microorganism (LAB $48 \mathrm{~h}$, enterobactericeae $24 \mathrm{~h}$, and yeasts and molds $72 \mathrm{~h}$ ).

Changes in chemical composition and WSC were analyzed as previously discussed for fresh material. The contents of organic acids were determined in a commercial laboratory (Dairy One Forage Laboratory, Ithaca, $\mathrm{NY}$ ) and $\mathrm{NH}_{3}-\mathrm{N}$ using an oxidation method (Strickland and Parson, 1972). Ambient temperature was obtained from the Agricultural Experimental Station meteorology data. Temperature of the silage mass was measured with thermometers (Sudbury Compost Thermometer, Baled Hay Compost, NASCO, Fort Atkinson, WI) located in the middle of three bales from each SM.

\section{Aerobic Stability}

Three bales from each SM were exposed to air for 3 $\mathrm{d}$ to evaluate the aerobic stability of the resulting silage. Bales were opened at two lengths of fermentation, 53 $\mathrm{d}$ (short) and $111 \mathrm{~d}$ (long). After 0,1 , and $3 \mathrm{~d}$ of aerobic exposure, three samples from each bale in each SM and LF were collected for analyses of $\mathrm{pH}$, changes in chemical composition, and fermentation end products as described previously. Enumeration of microorganisms responsible for aerobic deterioration, such as yeasts and molds (as described previously) and of total bacteria (Tryptic Soy Agar, Difco Laboratories, Detroit, MI) was conducted after $24 \mathrm{~h}$ of incubation. The temperature was measured as described above.

\section{Forage Intake}

In two trials $58 \mathrm{~d}$ apart, six Holstein heifers $(200 \mathrm{~kg}$; two per pen) were randomly assigned to pens located in a paved yard under saran shade and concrete floor to determine the intake of silages from each SM and LF (53 d in trial 1 and $111 \mathrm{~d}$ in trial 2). Silage was fed in the divided manger of each pen from a single bale of both SM and the same LF during $\mathrm{d} 0,1,2$, and $3 \mathrm{~d}$ of aerobic exposure. Drinking water was available ad libitum. To determine forage intake, each bale from each SM was always fed in the same pen. The weighed silage was provided at $0800 \mathrm{~h}$, and orts were weighed to determine DMI. Also, DMI expressed as a percentage of BW and DMI expressed as percentage of the offered material were calculated.

\section{Statistical Analysis}

The statistical analysis of the fermentation process data was conducted by a general lineal model in SAS (SAS, 1990) using a completely randomized design with a $2 \times 7$ factorial arrangement with three replicates. The Bonferroni test was used for the separation of means in principle effects and interactions. The model for the fermentative process was

$$
\mathrm{Y}_{\mathrm{ijk}}=\mu+\alpha_{\mathrm{i}}+\beta_{\mathrm{j}}+\alpha \beta_{\mathrm{ij}}+\epsilon \varepsilon_{\mathrm{ijk}}
$$


where:

$$
\begin{aligned}
\mathrm{Y}_{\mathrm{ijkm}}= & \text { individual response of a variable mea- } \\
& \text { sured (e.g. pH, fermentation end products) } \\
\mu= & \text { general mean } \\
\alpha_{\mathrm{i}}= & \text { effect of level } i \text { from SM } \\
\beta_{\mathrm{j}}= & \text { effect of level } j \text { from fermentation period } \\
\alpha \beta_{\mathrm{ij}}= & \text { effect of the interaction of level } i \text { from } \mathrm{SM} \\
& \text { and level } j \text { from fermentation period } \\
\varepsilon_{\mathrm{ijk}}= & \text { experimental error. }
\end{aligned}
$$

The split plot design in time was used to analyze the aerobic stability data with a model of random and fixed effects in triplicate. Bales from each SM and LF were considered as a plot, and the repetitive samples of days of aerobic exposure in each bale corresponding to each $\mathrm{SM}$ and LF as a subplot. The SM, LF, and day of aerobic exposure were considered as fixed effects and the bales as a random effect. Also, the Bonferroni test was used as described above. The model was

$$
\mathrm{Y}_{\mathrm{ijk}}=\mu+\alpha_{\mathrm{i}}+\delta_{\mathrm{ik}}+\beta_{\mathrm{j}}+\alpha \beta_{\mathrm{ij}}+\varepsilon_{\mathrm{ijk}}
$$

where:

$$
\begin{aligned}
\mathrm{Y}_{\mathrm{ijkm}}= & \text { individual response of a variable mea- } \\
& \text { sured (e.g. } \mathrm{pH}) \\
\mu= & \text { general mean } \\
\alpha_{\mathrm{i}}= & \text { effect of level } i \text { from SM } \\
\delta_{\mathrm{ik}}= & \text { experimental error for the plot }(\mathrm{LF}) \\
\beta_{\mathrm{j}}= & \text { effect of level } j \text { from days of aerobic expo- } \\
& \text { sure } \\
\alpha \beta_{\mathrm{ij}}= & \text { effect of the interaction of level } i \text { from SM } \\
& \text { and level } j \text { from days of aerobic exposure } \\
\varepsilon_{\mathrm{ijk}}= & \text { experimental error. }
\end{aligned}
$$

The statistical analysis of the forage intake data was conducted using a mixed model for random and fixed effects, where SM, LF, and day of aerobic exposure were considered as fixed effects, and bales from each SM and $\mathrm{LF}$ as random effects. The pens were considered as experimental units with three replicates. The correlation between observations in the same pen and the correlation of days of aerobic exposure in the same bale were considered in the mixed model. The model used was

$$
\begin{gathered}
\mathrm{Y}_{\mathrm{ijklm}}=\mu+\alpha_{\mathrm{i}}+\beta_{\mathrm{j}}+\alpha \beta_{\mathrm{ij}}+\delta_{\mathrm{k}(\mathrm{ij})}+\lambda_{\mathrm{l}}+\alpha \lambda_{\mathrm{il}}+\beta \lambda_{\mathrm{jl}} \\
+\alpha \beta \lambda_{\mathrm{ijl}}+\varepsilon_{\mathrm{ijklm}}
\end{gathered}
$$

where:

$$
\begin{aligned}
& \mathrm{Y}_{\mathrm{ijklm}}= \text { individual response of a variable mea- } \\
& \text { sured (e.g. CVMS) }
\end{aligned}
$$

\author{
$\mu=$ general mean \\ $\alpha_{\mathrm{i}}=$ effect of level $i$ from SM \\ $\beta_{\mathrm{j}}=$ effect of level $j$ from $\mathrm{LF}$ \\ $\alpha \beta_{\mathrm{ij}}=$ effect of the interaction of level $i$ from SM \\ and level $j$ from LF \\ $\delta_{\mathrm{k}(\mathrm{ij})} \quad$ effect of level $k$ of a bale in a SM and LF \\ $\lambda_{1}=$ effect of level $l$ from day of aerobic expo- \\ sure \\ $\alpha \lambda_{\text {il }} \quad$ effect of interaction between level $i$ from \\ $\mathrm{SM}$ and level $l$ from day of aerobic expo- \\ sure \\ $\beta \lambda_{\mathrm{jl}}=$ effect of the interaction between level $j$ \\ from LF and level $l$ from day of aerobic \\ exposure \\ $\alpha \beta \lambda_{\mathrm{ijl}}=$ effect of triple interaction \\ $\varepsilon_{\mathrm{ijklm}}=$ experimental error.
}

\section{RESULTS AND DISCUSSION}

\section{Vegetative Material}

Chemical composition of the fresh material prior to ensiling (Table 1) was typical of mature NTG that are characterized by high content of structural carbohydrates and low concentration of WSC (Chenost and Sansoucy, 1994; Catchpoole and Henzell, 1971). Also, a high percentage of DM (37.01\%) and low content of hemicellulose $(12.21 \%)$ and CP (3.75\%) are representative of forages in advanced stage of maturity and of poor nutritive quality (Vicente-Chandler et al., 1983). In addition, the epiphitic microbes present in the fresh material include a small population of LAB and a high concentration of coliforms, yeasts, and molds which also is characteristic of NTG (Rodríguez, 1996; Martínez, 1998).

\section{Fermentation Process}

The $\mathrm{pH}$, temperature, microbial populations (Table 2 ), chemical composition (Table 3), and fermentation end products (Table 4) were not affected by the SM of NTG ensiled in round bales. Thus the storage of round bales under shade or exposed to sunlight did not influence the fermentative parameters of NTG.

These results differ from previous studies in temperate climates, where it is recomended to stored round bales in shady areas (Vough and Glick, 1993; Garthe and Hall 1994; Kunkle, 2001). There is also disagreement with previous research conducted in the same tropical climate with micro-silos, which demonstrated that storage of NTG at controlled temperature (20 to $22^{\circ}$ ) resulted in more desirable fermentations than at higher ambient temperature (González, G., A. A. Rodríguez, and E. O. Riquelme, 1998 unpublished data). However, studies by other researchers using 
Table 1. Chemical composition and epiphitic microbes of the fresh material.

\begin{tabular}{|c|c|c|c|}
\hline \multicolumn{2}{|c|}{ Chemical composition } & \multicolumn{2}{|c|}{ Epiphitic microbes } \\
\hline Variable $^{1}$ & $\%$ & Variable & Log cfu/g fresh material \\
\hline DM & 37.01 & $\mathrm{LAB}^{2}$ & 1.52 \\
\hline Ash & 11.78 & Coliforms & 4.85 \\
\hline $\mathrm{OM}$ & 88.22 & Yeast and molds & 4.15 \\
\hline NDF & 72.54 & & \\
\hline $\mathrm{ADF}$ & 60.33 & & \\
\hline Hemicellulose & 12.21 & & \\
\hline Total nitrogen & 0.60 & & \\
\hline $\mathrm{CP}$ & 3.75 & & \\
\hline $\mathrm{WSC}^{3}$ & 0.18 & & \\
\hline
\end{tabular}

${ }^{1} \mathrm{DM}$ basis.

${ }^{2} \mathrm{LAB}=$ lactic acid-producing bacteria.

${ }^{3} \mathrm{WSC}=$ water soluble carbohydrates.

round bales to ensile tropical Napier grass (Yokota et al., 1991; Tamada et al., 1999) indicates that silage could be well preserved even at high temperatures (30 to $40^{\circ} \mathrm{C}$ ). The latter results agree with the present study and suggest that unfavorable characteristics of many tropical silages are due to intrinsic characteristics of the NTG rather than to high ambient temperatures during the fermentation.

Changes in $\mathrm{pH}$, temperature, microbial populations, chemical composition, and fermentation end products, during the fermentation process, were characteristic of NTG ensiled in round bales and are in agreement with previous research (Weiss and Underwood, 1995; Pantoja et al., 1999; Rodríguez et al., 2000). Moreover, $\mathrm{pH}$ values were above 5.0 , and that is representative of an unstable fermentation and characteristic of ensiled forages with high contents of structural carbohydrates and low WSC content. These conditions did not provide adequate substrates necessary for the establishment of $\mathrm{LAB}$ and were an excellent environment for the proliferation and dominance of coliforms, yeasts, and molds.
Acetic acid was the primary fermentation end product, which is an indicator of extended fermentation and high buffering capacity characteristic of forages ensiled in round bales (Garthe and Hall, 1994; Kung and Shaver, 2001; Kunkle, 2001). The content of lactic acid increased gradually during the fermentation process, reaching its highest concentration at $53 \mathrm{~d}$ of fermentation. However, lactic acid content did not reach the desirable level of $1.5 \%$, indicating a poor fermentation (McCullough, 1984). Changes in lactic acid content observed in this study agree with concurrent changes in $\mathrm{pH}$ and $\mathrm{LAB}$ populations during the fermentation process. Also, the improvements in temperature and acetic acid content at $111 \mathrm{~d}$ could indicate a dominance of heterofermentative LAB at the end of the fermentation process. Likewise, changes in chemical composition, microbial population, and the production and possible microbial utilization of organic acids, indicate a possible change in fermentation patterns after $25 \mathrm{~d}$ as a consequence of unstable fermentations.

Percentage of $\mathrm{NH}_{3}-\mathrm{N} /$ total-N increased gradually during the fermentation process, reaching its highest

Table 2. Fermentation characteristics of native tropical grasses (NTG) ensiled in round bales and stored in shade or sunlight.

\begin{tabular}{|c|c|c|c|c|c|c|c|c|c|c|c|c|c|c|}
\hline \multirow[b]{2}{*}{ Variable } & \multicolumn{2}{|c|}{ Storage (S) } & \multirow[b]{2}{*}{$\mathrm{SE}$} & \multicolumn{7}{|c|}{ Length of fermentation (L) } & \multirow[b]{2}{*}{$\mathrm{SE}$} & \multicolumn{3}{|c|}{ Probability } \\
\hline & Shade & Sunlight & & 0 & 1 & 4 & 11 & 25 & 53 & 111 & & $\mathrm{~S}^{1}$ & $\mathrm{~L}^{2}$ & $\mathrm{~S} \times \mathrm{L}^{3}$ \\
\hline $\mathrm{pH}$ & 5.71 & 5.75 & 0.06 & $6.41^{\mathrm{a}}$ & $6.06^{\mathrm{a}}$ & $6.18^{\mathrm{a}}$ & $6.04^{\mathrm{a}}$ & $5.20^{\mathrm{b}}$ & $5.00^{\mathrm{b}}$ & $5.25^{\mathrm{b}}$ & 0.12 & NS & $*$ & NS \\
\hline $\mathrm{LAB}^{5}$ & 5.00 & 5.39 & 0.15 & $1.52^{\mathrm{b}}$ & $5.31^{\mathrm{a}}$ & $5.92^{\mathrm{a}}$ & $5.56^{\mathrm{a}}$ & $6.28^{\mathrm{a}}$ & $6.10^{\mathrm{a}}$ & $5.69^{\mathrm{a}}$ & 0.28 & NS & $*$ & NS \\
\hline Coliforms & 6.33 & 6.22 & 0.33 & $4.85^{\mathrm{b}}$ & $7.84^{\mathrm{a}}$ & $7.45^{\mathrm{ab}}$ & $6.42^{\mathrm{ab}}$ & $6.35^{\mathrm{ab}}$ & $6.14^{\mathrm{ab}}$ & $4.88^{\mathrm{b}}$ & 0.61 & NS & $*$ & NS \\
\hline Yeast and molds & 3.93 & 4.21 & 0.14 & $4.15^{\mathrm{a}}$ & $5.31^{\mathrm{a}}$ & $7.45^{\mathrm{a}}$ & $6.42^{\mathrm{a}}$ & $3.92^{\mathrm{ab}}$ & $4.42^{\mathrm{a}}$ & $2.77^{\mathrm{b}}$ & 0.26 & NS & $*$ & NS \\
\hline
\end{tabular}

\footnotetext{
${ }^{\mathrm{a}, \mathrm{b}}$ Means in sub columns within row with different subscript differ $(P<0.05)$

${ }^{1} \mathrm{~S}=$ effect of storage method.

${ }^{2} \mathrm{~L}=$ effect of length of fermentation.

${ }^{3} \mathrm{~S} \times \mathrm{L}=$ interaction storage method and length of fermentation.

${ }^{4} \mathrm{Log} \mathrm{CFU} / \mathrm{g}$ of fresh material.

${ }^{5} \mathrm{LAB}=$ lactic acid-producing bacteria.
} 
Table 3. Chemical composition of native tropical grasses (NTG) ensiled in round bales and stored in shade or sunlight.

\begin{tabular}{|c|c|c|c|c|c|c|c|c|c|c|c|c|c|c|}
\hline \multirow[b]{2}{*}{ Variable $(\%)^{1}$} & \multicolumn{2}{|c|}{ Storage (S) } & \multirow[b]{2}{*}{$\mathrm{SE}$} & \multicolumn{7}{|c|}{ Length of fermentation (L) } & \multirow[b]{2}{*}{$\mathrm{SE}$} & \multicolumn{3}{|c|}{ Probability } \\
\hline & Shade & Sunlight & & 0 & 1 & 4 & 11 & 25 & 53 & 111 & & $\mathrm{~S}^{2}$ & $\mathrm{~L}^{3}$ & $\mathrm{~S} \times \mathrm{L}^{4}$ \\
\hline DM & 45.57 & 45.59 & 0.51 & $37.01^{\mathrm{c}}$ & $46.95^{\mathrm{ba}}$ & $45.82^{\mathrm{b}}$ & $45.94^{\mathrm{b}}$ & $46.92^{\mathrm{ba}}$ & $45.94^{\mathrm{b}}$ & $50.47^{\mathrm{a}}$ & 0.95 & NS & $*$ & NS \\
\hline $\mathrm{OM}$ & 87.46 & 87.16 & 0.45 & 88.22 & 86.97 & 86.96 & 88.30 & 85.93 & 87.31 & 87.48 & 0.84 & NS & NS & NS \\
\hline NDF & 72.20 & 72.36 & 0.46 & $72.54^{\mathrm{bc}}$ & $74.36^{\mathrm{ab}}$ & $76.80^{\mathrm{a}}$ & $75.87^{\mathrm{ab}}$ & $69.75^{\mathrm{cd}}$ & $69.22^{\mathrm{cd}}$ & $67.41^{\mathrm{d}}$ & 0.87 & NS & $*$ & NS \\
\hline $\mathrm{ADF}$ & 58.86 & 58.64 & 0.36 & $60.33^{\mathrm{a}}$ & $58.07^{\mathrm{ab}}$ & $59.15^{\mathrm{ab}}$ & $58.70^{\mathrm{ab}}$ & $60.43^{\mathrm{a}}$ & $58.06^{\mathrm{ab}}$ & $56.51^{\mathrm{b}}$ & 0.68 & NS & $*$ & NS \\
\hline $\mathrm{HC}^{5}$ & 13.33 & 13.72 & 0.55 & $12.21^{\mathrm{bc}}$ & $16.29^{\mathrm{ab}}$ & $17.65^{\mathrm{a}}$ & $17.17^{\mathrm{a}}$ & $9.31^{\mathrm{c}}$ & $11.16^{\mathrm{c}}$ & $10.90^{\mathrm{c}}$ & 1.03 & NS & $*$ & NS \\
\hline $\mathrm{WSC}^{7}$ & 0.52 & 0.52 & 0.01 & $0.18^{\mathrm{c}}$ & $0.48^{\mathrm{b}}$ & $0.41^{\mathrm{b}}$ & $0.37^{\mathrm{bc}}$ & $0.49^{\mathrm{b}}$ & $0.80^{\mathrm{a}}$ & $0.90^{\mathrm{a}}$ & 0.01 & NS & $*$ & NS \\
\hline
\end{tabular}

${ }^{\mathrm{a}, \mathrm{b}}$ Means in sub columns within row with different subscript differ $(P<0.05)$.

${ }^{1} \mathrm{DM}$ basis.

${ }^{2} \mathrm{~S}=$ effect of storage method.

${ }^{3} \mathrm{~L}=$ effect of length of fermentation.

${ }^{4} \mathrm{~S} \times \mathrm{L}=$ interaction storage method and length of fermentation.

${ }^{5}$ Hemicellulose.

${ }^{6} \mathrm{TN}=$ total nitrogen.

${ }^{7} \mathrm{WSC}=$ water soluble carbohydrates.

concentration at $25 \mathrm{~d}$ of fermentation. This, and results from other variables studied, may indicate that in this experiment the undesirable secondary fermentations, typical of tropical forages, occurred after 25 to $53 \mathrm{~d}$ of ensiling.

\section{Aerobic Stability}

Lower $\mathrm{pH}$ values were observed in association with higher content of lactic acid $(P<0.05)$, lower temperatures and lower populations of total bacterial and yeast and molds $(P<0.05)$ in round bales stored under shade compared with those stored under direct sunlight, upon exposure to aerobic conditions (Table 5). However, the content of WSC after aerobic exposure was similar for both SM. There is limited information about aerobic stability of round bale silage and of the effect of environmental temperature on its deterioration during storage.
However, in this experiment, it can be inferred that the effect of environmental temperature and direct solar radiation was greater on the microorganisms associated with aerobic deterioration (yeast and molds) than on the microbes associated with fermentation.

It has been postulated that microbial populations associated with aerobic deterioration, during the fermentation period, are directly correlated with aerobic instability of silages (Courtin and Spoelstra, 1990; Muck and O'Kiely, 1992; O'Kiely and Muck, 1992). However, factors affecting their proliferation, are unclear. It has been suggested that high temperatures could promote yeast and mold populations (Ohyama et al., 1975; Henderson et al., 1979), possibly explaining results obtained in this experiment.

For both LF, the temperature of silage stored under direct sunlight was higher $(P<0.05)$ than of that stored under shade when exposed to aerobic conditions for $3 \mathrm{~d}$.

Table 4. Fermentation end products of native tropical grasses (NTG) ensiled in round bales and stored in shade or sunlight.

\begin{tabular}{|c|c|c|c|c|c|c|c|c|c|c|c|c|c|c|}
\hline \multirow[b]{2}{*}{ Variable $(\%)$} & \multicolumn{2}{|c|}{ Storage (S) } & \multirow[b]{2}{*}{$\mathrm{SE}$} & \multicolumn{7}{|c|}{ Day of fermentation (L) } & \multirow[b]{2}{*}{$\mathrm{SE}$} & \multicolumn{3}{|c|}{ Probability } \\
\hline & Shade & Sunlight & & 0 & 1 & 4 & 11 & 25 & 53 & 111 & & $\mathrm{~S}^{1}$ & $\mathrm{~L}^{2}$ & $\mathrm{~S} \times \mathrm{L}^{3}$ \\
\hline Lactic & 0.07 & 0.07 & 0.01 & $0.01^{\mathrm{c}}$ & $0.02^{\mathrm{c}}$ & $0.05^{\mathrm{bc}}$ & $0.05^{\mathrm{bc}}$ & $0.09^{\text {ba }}$ & $0.12^{\mathrm{a}}$ & $0.13^{\mathrm{a}}$ & 0.01 & NS & $*$ & NS \\
\hline Propinic & 0.00 & 0.00 & 0.00 & $0.00^{\mathrm{b}}$ & $0.00^{\mathrm{b}}$ & $0.00^{\mathrm{b}}$ & $0.00^{\mathrm{b}}$ & $0.00^{\mathrm{b}}$ & $0.00^{\mathrm{b}}$ & $0.01^{\mathrm{a}}$ & 0.00 & NS & * & NS \\
\hline Isobutyric & 0.02 & 0.03 & 0.00 & $0.00^{\mathrm{b}}$ & $0.00^{\mathrm{b}}$ & $0.00^{\mathrm{b}}$ & $0.01^{\mathrm{b}}$ & $0.05^{\mathrm{a}}$ & $0.06^{\mathrm{a}}$ & $0.08^{\mathrm{a}}$ & 0.01 & NS & $*$ & NS \\
\hline Butyric & 0.005 & 0.002 & 0.00 & $0.00^{\mathrm{b}}$ & $0.00^{\mathrm{b}}$ & $0.00^{\mathrm{b}}$ & $0.00^{\mathrm{b}}$ & $0.00^{\mathrm{b}}$ & $0.00^{\mathrm{b}}$ & $0.05^{\mathrm{a}}$ & 0.01 & NS & $*$ & NS \\
\hline $\mathrm{NH}_{3}-\mathrm{N}$ & 0.01 & 0.01 & 0.00 & $0.00^{\mathrm{c}}$ & $0.01^{\mathrm{b}}$ & $0.01^{\mathrm{b}}$ & $0.01^{\mathrm{b}}$ & $0.02^{\mathrm{a}}$ & $0.02^{\mathrm{a}}$ & $0.02^{\mathrm{a}}$ & 0.00 & NS & $*$ & NS \\
\hline
\end{tabular}

${ }^{\mathrm{a}, \mathrm{b}}$ Means in sub columns within row with different subscript differ $(P<0.05)$.

${ }^{1} \mathrm{~S}=$ effect of storage method.

${ }^{2} \mathrm{~L}=$ effect of day of fermentation.

${ }^{3} \mathrm{~S} \times \mathrm{L}=$ interaction storage method and day of fermentation. 


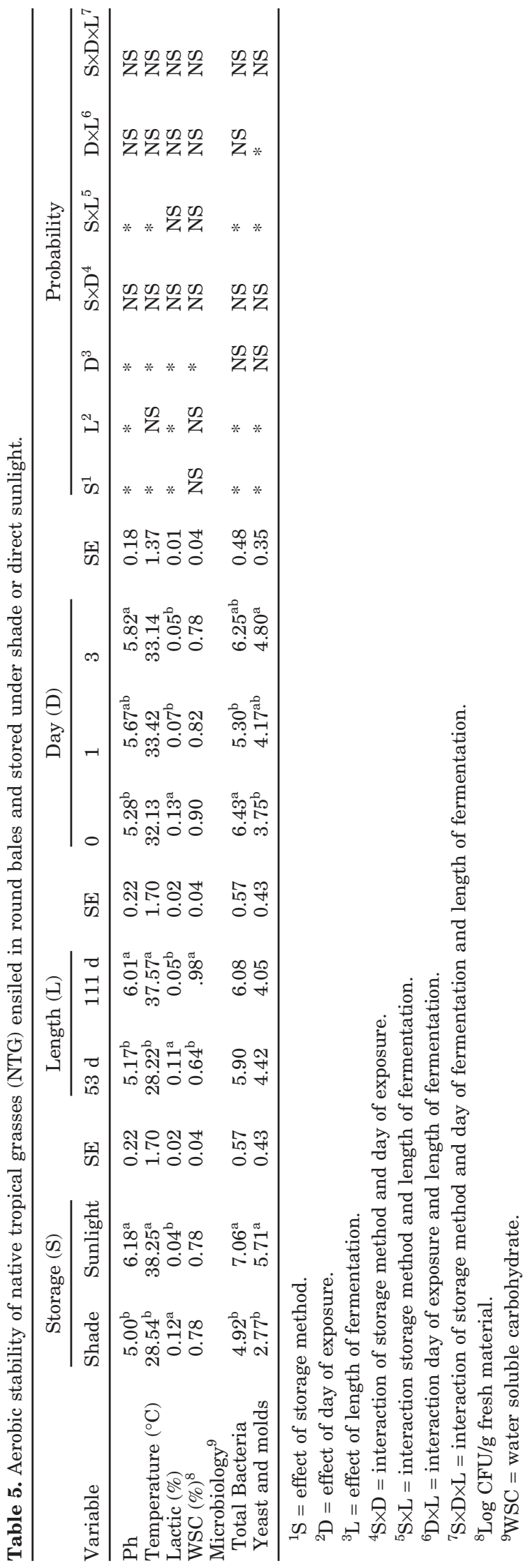

Table 6. Means of indicative variables of aerobic stability between $\mathrm{SM}$ at each LF.

\begin{tabular}{|c|c|c|c|c|}
\hline \multirow[b]{2}{*}{ Variable } & \multirow[b]{2}{*}{ Length } & \multicolumn{2}{|c|}{ Storage } & \multirow[b]{2}{*}{$\mathrm{SE}$} \\
\hline & & Shade & Sunlight & \\
\hline $\mathrm{pH}$ & $53 \mathrm{~d}$ & $\begin{array}{l}5.23 \\
476^{b}\end{array}$ & $\begin{array}{l}5.11 \\
7.25^{\mathrm{a}}\end{array}$ & $\begin{array}{l}0.32 \\
0.32\end{array}$ \\
\hline Temperature $\left({ }^{\circ} \mathrm{C}\right)$ & $\begin{array}{l}53 \mathrm{~d} \\
111 \mathrm{~d}\end{array}$ & $\begin{array}{l}28.13 \\
26.95^{\mathrm{b}}\end{array}$ & $\begin{array}{l}28.32 \\
48.20^{\mathrm{a}}\end{array}$ & $\begin{array}{l}.02 \\
2.4 \\
2.4\end{array}$ \\
\hline Microbiology $^{1}$ & & & & \\
\hline Total Bacteria & $\begin{array}{l}53 \mathrm{~d} \\
111 \mathrm{~d}\end{array}$ & $\begin{array}{l}5.58 \\
4.25^{\mathrm{b}}\end{array}$ & $\begin{array}{l}6.22 \\
7.91^{\mathrm{a}}\end{array}$ & $\begin{array}{l}0.81 \\
0.81\end{array}$ \\
\hline Yeasts and molds & $\begin{array}{l}53 \mathrm{~d} \\
111 \mathrm{~d}\end{array}$ & $\begin{array}{l}4.04 \\
1.50^{b}\end{array}$ & $\begin{array}{l}4.80 \\
6.61^{\mathrm{a}}\end{array}$ & $\begin{array}{l}0.61 \\
0.61\end{array}$ \\
\hline
\end{tabular}

These results could be associated with higher microbial populations responsible for aerobic deterioration in bales stored under direct sunlight and exposed to aerobic conditions, resulting in higher heat production and therefore unstable silages.

Round-bale silage exposed to air after $53 \mathrm{~d}$ of fermentation had lower $(P<0.05) \mathrm{pH}$, temperature and WSC, and higher lactic acid content than silage exposed to aerobic conditions after $111 \mathrm{~d}$. Results of $\mathrm{pH}$, temperature and lactic acid, suggest higher instability in silages exposed to air after long periods of fermentation. The present findings differ from previous studies in which forage sorghum (Sorghum sudangrass) ensiled in laboratory microsilos, was less stable when exposed to air after $40 \mathrm{~d}$ of fermentation than when exposed after 100 d (Rodríguez, 1996). As in previous studies with tropical forages, independently of SM and LF, aerobic deterioration of silages progressed with days of aerobic exposure (Rodríguez, 1996; Arias, 1998; Martínez, 1998).

An interaction between SM and LF was observed on aerobic stability of silages of NTG (Table 6). Acidity, temperature, and microbial populations were similar for silages of both SM with $53 \mathrm{~d}$ of fermentation. However, bales stored under shade and exposed to air after $111 \mathrm{~d}$ had lower $(P<0.05) \mathrm{pH}$, temperature, and populations of total bacteria and yeast and molds than silages stored under direct sunlight and exposed to aerobic conditions after $111 \mathrm{~d}$ of fermentation. These results suggest, that storage of round bales under shade could be advantageous only if the LF is more than 4 mo.

\section{Forage Intake}

All forage intake criteria evaluated, DMI, DMI expressed as a percentage of BW, and DMI expressed as percentage of the offered material were similar for both SM and days of aerobic exposure (Table 7). Values of DMI were higher in silages of NTG exposed to air after 
Table 7. Dry matter intake of native tropical grasses (NTG) ensiled in round bales and stored under shade or direct sunlight during both length of fermentation (LF) and exposed to air for $3 \mathrm{~d}$.

\begin{tabular}{|c|c|c|c|c|c|c|c|c|c|c|c|c|c|c|c|c|c|c|}
\hline \multicolumn{3}{|c|}{ Storage (S) } & $\mathrm{SE}$ & \multicolumn{2}{|c|}{ Length (L) } & $\mathrm{SE}$ & \multicolumn{4}{|c|}{ Day (D) } & $\mathrm{SE}$ & \multicolumn{7}{|c|}{ Probability } \\
\hline DMI & 4.19 & 4.33 & 0.19 & $3.96^{\mathrm{b}}$ & $4.65^{\mathrm{a}}$ & 0.25 & 3.85 & 4.22 & 4.37 & 4.78 & 0.26 & NS & NS & $*$ & NS & NS & * & NS \\
\hline $\mathrm{DMIOM}^{9}$ & 97.44 & 83.03 & 6.29 & 88.38 & 92.04 & 3.20 & 91.34 & 93.08 & 90.02 & 86.49 & 5.49 & NS & NS & NS & NS & NS & NS & NS \\
\hline
\end{tabular}

${ }^{\mathrm{a}, \mathrm{b}}$ Means in sub columns within row with different subscript differ $(P<0.05)$.

${ }^{1} \mathrm{~S}=$ effect of storage method.

${ }^{2} \mathrm{D}=$ effect of day of exposure.

${ }^{3} \mathrm{~L}=$ effect of length of fermentation.

${ }^{4} \mathrm{~S} \times \mathrm{D}=$ interaction of storage and day of exposure.

${ }^{5} \mathrm{~S} \times \mathrm{L}=$ interaction of storage and length of fermentation.

${ }^{6} \mathrm{D} \times \mathrm{L}=$ interaction of day of exposure and length of fermentation.

${ }^{7} \mathrm{~S} \times \mathrm{D} \times \mathrm{L}=$ interaction of storage method and day of exposure and length of fermentation.

${ }^{8} \mathrm{DMI}$ expressed as percentage of BW.

${ }^{9} \mathrm{DMI}$ expressed as percentage of offered OM.

$111 \mathrm{~d}$ of fermentation than those fermented for $53 \mathrm{~d}$; however, DMI expressed as a percentage of BW and DMI expressed as percentage of the offered material did not differ. Part of the difference in DMI could be explained, by increased physical capacity of the growing animals (mean BW: for LF $53 \mathrm{~d}=205.7 \mathrm{~kg}$ and for $\mathrm{LF}$ $111 \mathrm{~d}=212.7 \mathrm{~kg}$ ), and not be due only to the matter of animal acceptance. Also, DMI and DMI expressed as a percentage of BW, of heifers fed NTG silages fermented for $53 \mathrm{~d}$ were higher $(P<0.05)$ on $\mathrm{d} 2$ of aerobic exposure; whereas, DMI was higher in NTG silages fermented for $111 \mathrm{~d}$ on the first day of exposure to aerobic conditions (Table 8). In this study, SM did not affect DMI, which indicates that less deterioration of silages when exposed to air does not necessarily lead to higher DMI. Per unit of BW, DMI was similar for both LF and inferior to DMI normally expected in growing heifers.

The typical characteristics of NTG (low CP and high cell wall content and addition to large particle size in silages), result in low passage rate and long reticulumrumen retention time, which reduces available space for new ingested material (Catchpoole and Henzell, 1997). Throughout the aerobic exposure period, silages fer- mented for $53 \mathrm{~d}$ were consumed more consistently than those fermented for $111 \mathrm{~d}$.

\section{CONCLUSIONS}

Storage of round bales under roof did not improve fermentation characteristics or chemical composition of native tropical grass silage. However, this type of storage during a short length of fermentation ( $53 \mathrm{~d}$ ) resulted in silage more resistant to aerobic deterioration. These results suggest that high temperatures both day and night in the tropics and not direct sunlight exposure may be primarily responsible for the extensive fermentation and enhance aerobic deterioration in round bale silages. Nutritive value was not improved by storage under roof regardless of length of fermentation.

Considering the advantages to be gained from decreased aerobic deterioration and possible improvements in nutritive value, it is preliminarily recommended to store round bales under roof only if the storage period is less than $2 \mathrm{mo}$. It is not possible to recommend this practice for longer fermentation periods because no benefits were obtained in this experi-

Table 8. Means of DMI of native tropical grasses (NTG) silage for each length of fermentation at each day of aerobic exposure.

\begin{tabular}{lllllll}
\hline & & \multicolumn{5}{c}{ Day } \\
\cline { 3 - 6 } Variable & Length & 0 & 1 & 2 & 3 & SE \\
\hline DMI $(\mathrm{kg})$ & $53 \mathrm{~d}$ & 3.30 & 4.12 & 4.54 & 3.85 & 0.44 \\
& $111 \mathrm{~d}$ & $4.40^{\mathrm{a}}$ & $4.32^{\mathrm{b}}$ & $4.19^{\mathrm{b}}$ & $5.70^{\mathrm{a}}$ & 0.22 \\
$\operatorname{DMIBW}^{1}(\%)$ & $53 \mathrm{~d}$ & 1.93 & 2.33 & 2.54 & 2.20 & 0.28 \\
& $111 \mathrm{~d}$ & $1.93^{\mathrm{a}}$ & $1.90^{\mathrm{a}}$ & $1.83^{\mathrm{b}}$ & $2.59^{\mathrm{a}}$ & 0.18 \\
\hline
\end{tabular}

${ }^{\mathrm{a}, \mathrm{b}}$ Means in sub columns within row with different subscript differ $(P<0.05)$.

${ }^{1} \mathrm{DMI}$ expressed as percentage of $\mathrm{BW}$. 
ment, and this practice increases costs of labor and machinery. To determine the final effectiveness of this practice studies considering the economic costs and benefits are recommended.

\section{REFERENCES}

AOAC.1990. Official Methods of Analysis. 15th Ed. Association of Official Analytical Chemists. Arlington, VA.

Arias, F. 1998. Características fermentativas y estabilidad aeróbica de dos variedades de maíz tropical y hierba guinea ensilada a diferentes estados de madurez. M.S. Thesis, Universidad de Puerto Rico, Recinto de Mayagüez.

Catchpoole, V. R., and E. F. Henzell. 1971. Silage and silage-making from tropical herbage species. Herbage, 41:213-221(Abstr.).

Chenost, M., and R. Sansoucy. 1994. Nutritional characteristics of tropical feed resources: natural and improve grasslands, crop residues and agro-industrial by-products in Feeding dairy cows in the tropics. FAO Anim. Prod. Health Papers 86:66-81.

Courtin, M. G., and S. F. Spoelstra. 1990. A simulation model of the microbiological and chemical changes accompanying the initial stage of aerobic deterioration of silage. Grass Forage Sci. 45:153-165.

Dubois, M., K. A. Gilles, J. K. Hamilton, P. A. Rebers and F. Smith. 1956. Colorimetric method for determination of sugar and related substances. Anal. Chem. 28:350.

Garthe, J. W., and M. H. Hall. 1994. Large round bale silage. Pennsylvania State College Agric. Sci., Cooperative Extension Service. Agronomy Facts 9.

Harrison, J. H., R. Blauwiekel, and M. R. Stokes. 1994. Symposium: Utilization of grass silage. Fermentation and utilization of grass silage. J. Anim. Sci. 77:3209-3235.

Henderson, A. R., J. M. Ewart, and G. M. Robertson. 1979. Studies on the aerobic stability of commercial silages. J. Sci. Food Agric. 30:223-228.

Kung, L., and R. Shaver. 2001. Interpretation and use of silage fermentation analysis reports. Wisconsin team forage, Focus on forage 13(13):20-28

Kunkle, W. E. 2001. Harvesting, storing and feeding forages as round bale silage. Pages 102-112 in Proc. 12th Ann. Florida Ruminant Nutr. Symp.

Martínez, J. L. 1998. Efecto de la tasa de aplicación de aditivos comerciales sobre las características fermentativas y estabilidad aeróbica de forrajeras ensiladas en ambientes tropicales. M.S. Thesis, Universidad de Puerto Rico, Recinto de Mayagüez.

McCullough, M. E. 1984. Feeding Quality Silage. Anim. Nutr. Health 39:30-35.

Muck, R. E., and P. O’Kiely. 1992. Aerobic deterioration of lucerne (Medicago sativa) and maize (Zea mais) silages-Effects of fermentation products. J. Sci. Food Agric. 59:145-149.
Ohyama, Y., S. Masaki, and S. Hara. 1975. Factors influencing aerobic deterioration of silages and changes in chemical composition after opening silos. J. Sci. Food Agric. 26:1137-1147.

O'Kiely, P., and R.E. Muck. 1992. Aerobic deterioration of lucerne (Medicago sativa) and maize (Zea mais) silages-Effects of yeasts. J. Sci. Food Agric. 59:139-144.

Pantoja, J., C. Saavedra, A. Rodríguez and S. Morales. 1999. Efectos de la hora y tiempo de marchitamiento sobre características fermentativas de yerba estrella ensilada con o sin inóculo bacterial. Page 10 in SOPCA, Reunión Científica Anual. Mayagüez, Puerto Rico.

Rodríguez, A. A. 1996. Studies on the efficiency of a homofermentative lactic-acid producing bacterial inoculant and commercial cell wall degrading enzyme mixtures to enhance the fermentation characteristics and aerobic stability of forages ensiled in temperate and tropical environments. Ph.D. Diss. Michigan State University, East Lansing, MI

Rodríguez, A. A., D. Cianzio, G. González, L. Añeses, and E. O. Riquelme. 2000. Características fermentativas de pasturas tropicales nativas ensiladas en pacas cilíndricas. XVI Reunión de la Asociación Latinoamericana de Producción Animal. Montevideo, Uruguay.

Rodríguez, A. A., E. O. Riquelme, and J. A. Acevedo. 1998. Effect of temperature on the aerobic stability of forage sorghum silage. J. Anim. Sci. 81(Suppl.1):193.

SAS/STAT User's Guide, 4th ed. 1990. SAS Inst. Inc., Cary, NC.

Strickland, J. and S. Parson. 1972. Practical Handbook of Sea Water Analysis. Toronto, Canada.

Tamada, J., H. Yokota, M. Ohshima and M. Tamaki. 1999. Effect of additives, storage temperature and regional differences of ensiling on the fermentation quality of napier grass (Pennisetum purpureun Shum.) silage. Asian-Australas. J. Anim. Sci. 12:28-35.

Van Soest, P. J. 1994. Nutritional Ecology of the Ruminant. 2nd ed. Comstock Publ. Assoc., Ithaca, NY.

Vicente-Chandler, J., R. Caro Costas, F. Abruña, and S. Silva. 1983. Producción y utilización intensiva de las forrajeras en Puerto Rico. Estación Experimental Agrícola, UPR-RUM, Boletín 271.

Vough, L. R., and I. Glick. 1993. Round bale silage. In: Silage Production: From Seed to Animal. NRAES Publ. 67:117-123. Coop. Ext. Serv., Riley-Robb Hall, Ithaca, NY.

Weinberg, Z. G., G. Ashbell, Y. Hen, and A. Azriell. 1993. The effect of applying lactic acid bacteria at ensiling on the aerobic stability of silage. J. Appl. Bacteriol. 75:512-518.

Weinberg, Z. G., G. Szakacs, G. Ashbell, and Y. Hen. 2001. The effect of temperature on the ensiling process of corn and wheat. J. Appl. Bacteriol. 90(4):561-566.

Weiss, B., and J. Underwood. 1995. Round Bale Silage. The Ohio State University Extension, Agronomy Facts No. AGF-010-95.

Wilkinson, J. M. 1983. Silage made from tropical and temperate crops. Part I. The ensiling process and its influence on feed value. World Anim Rev. 45:36-42.

Yokota, H., T. Okajima, and M. Ohshima. 1991. Effect of environmental temperature and addition of molasses on the quality of Napier Grass (Pennisetum purpureum Schum.) silage. Asian-Austral. J. Anim. Sci. 4:377-382. 